UDC 81'255:378.147

DOI https://doi.org/10.31392/NPU-nc.series5.2020.72-1.45

Ihnatenko V. D., Pylypei Yu. A.

\title{
PERSONALITY-ACTIVITY APPROACH TO AUTONOMOUS FORMATION OF THE COMPETENCE IN TRANSLATION
}

The article is devoted to the problem of autonomous formation of the competence in translation in the context of a personalactivity approach to the learning process. The article describes the concept and place of students 'autonomous work in the modern educational process. Attention is focused on the personality-activity approach as an effective means of realization of modern educational goals, which maximally satisfies educational and cognitive needs of modern students. The concept of personalityactivity approach in the historical context is also analyzed. The personality-activity approach is considered in two aspects, namely, personal and activity, which are interrelated and just relative. The personal component is aimed at the formation of a secondary linguistic personality that is relevant to future philologists and provides the development of the individual as a whole. The activity component is based on the principles of subject-subject relations between students and the teacher, on equal partnership cooperation, which implies intensive educational and cognitive activity of students, in particular learning, when the student learns language and culture, being an active participant in the educational process but not observer / listener. It provides a positive intellectual-emotional context of learning activities, the opportunity for everyone to show his/her own activity, creativity and independence. Thus, the central categories of personality-activity approach in the context of autonomous work are secondary linguistic personality and independent, self-directed and productive activity of students, for the realization of which the main and effective means of learning scientists consider electronic means of education, to be precise, remote technologies, which allow to realize purposeful and methodically organized leadership of educational and cognitive activity of those who study and is based on the use of a wide range of traditional, informational and communicational technologies.

Key words: personality-activity approach, competence in translation, educational independent activity, foreign language.

\section{(статтю подано мовою оригіналу)}

Due to the development of international relations and integration of Ukraine into the European and world political and economic community, the role of translation is extremely important. Scientific and technological progress covers almost all spheres of life, increasing the number of different kinds of contacts not only between states but also between multilingual communities of people, including professional ones. The flow of information knows neither boundaries nor time. The endless diversity of the modern world is conveyed through the modern media in the sensations and interpretations of numerous participants in a single international information space, with the translator at the center. In such trends, the role of translation as a means of communication and support for economic, socio-political, scientific, cultural and aesthetic and other relations between peoples is greatly increased.

Today, the training of translators in higher education institutions in Ukraine is developing dynamically. The increasing volume and diversification of translation requirements as a professional activity have led to a change in the translation services market. Traditional ideas about translation work are changing, and the professional model of the translator is complicated, which, in turn, requires modernization of the process of preparation of future translators.

Today the task of higher education institutions is not only to give a certain amount of knowledge, but to teach how to draw independent conclusions on the basis of this knowledge, to think creatively, what is an extremely important factor of success in the professional activity of future translators. At the same time, it is important to develop the ability to independently replenish own knowledge, to navigate in the rapidly growing flow of various information [4, p. 19-23].

That is, the emphasis shifts to the students' ability to learn autonomously as the capability of the individual to realize their own needs, interests and satisfy them through the free choice of methods, forms and means of learning that are effective for mastering the necessary basic or additional knowledge in a particular discipline [10, p. 38-39].

We share the point of view of I. Zymniaia [15] on understanding the concept of "independent work". The scientist characterizes independent work as educational activity, which is organized by the student in accordance with his internal cognitive motives, according to the offered program, and is performed in a rational for him timing, selfcontrolled in the learning process under the condition of external indirect system control by the lecturer (professor, training computer programs, display technology) that is emphasizes the active nature of the students' independent work.

Whereas independent learning of written translation requires educational and cognitive activity of the individual, the learning process itself must be based on the principles of personality-activity approach.

In our opinion, the use of personality-activity approach is necessary because the process of learning written types of translation implies independent educational and cognitive activity of future philologists in extra-curricular conditions and is aimed at meeting their educational needs as subjects of this activity and professional needs in the process of professional activity.

Fundamentals of personality-activity approach were laid in psychology by the works of L. Vygotskoi, O. Leontiev, S. Rubinshtein, B. Ananiev, in which the person was considered as the subject of activity, formed in the activity 
and in communication with other people, determines the nature of this activity and communication [12, p. 75]. The ideas of the personality-activity approach were generalized and largely developed in the works of I. Zymniaia [15].

The personality-activity approach is treated by I. Zymniaia as a unity of personal and activity constituents, although naturally, such division is conditional and is carried out purely for gnostic purposes.

First and foremost, the personal component of the personality-activity approach is oriented at the student as a personality. In the context of language education, it refers to the formation of a linguistic personality, and in terms of I. I. Khaleevoi , a secondary linguistic personality - any native speaker of one or another language, which is characterized on the basis of the texts analysis he has created in terms of using the means of that language in order to reflect the surrounding reality (world picture) [13, p. 60].

Thus, the personal component involves the development of the individual as a whole, creating conditions for the development of his qualities, orientation to his individual experience, opportunities, needs, interests. Personal approach determines the leading orientation, the main content and the main criterion for successful learning not only knowledge, skills and ability, functional readiness to perform certain activities, but also the formation of a number of personal qualities: orientation focus, civic activity, creativity, ability, will, emotional sphere, character traits.

Therefore, a personality-oriented component involves the formation of a secondary linguistic personality, characterized by creativity, autonomy and ability for social interaction [15, p. 39].

The activity component in the context of personality-activity approach is based mainly on the principle of the subject-subjective relations of the teacher and students, activity, in the general-psychological - the theory of activity of O. M. Leontiev [5].

The activity component involves the orientation of learning on the organization of intensive educational and cognitive activity of students, which is constantly complicated, because only through their own activities, including studying, the student learns science and culture, ways of knowing and transforming the world, shapes and improves personal qualities. In this sense, activity is an open system for the formation of personality. Interpreting the activity approach as such a way of organizing educational and cognitive activity of students, in which they take an active part in the educational process. It is necessary to organize the education in such a format that students are active participants, subjects of learning, who are aware and identify the problem, set the purpose of studying a particular issue, formulate problems, solve them, apply the acquired knowledge in practice.

Following N. Gal'skova [2] we believe that it is important to provide the intellectual-emotional context of educational process, the ability of each, even the weakest student, to show their own activity, creativity and independence [2, pp. 148-149]. Such training implies a certain structural organization of the student's educational activity: development of communicative and cognitive need through interest in learning, development of the need to improve performance, creating a situation of intellectual difficulties through intellectual problem of content, speech by way of solving and organizing reflection of students about their own level of knowledge ability and determination of causes which create difficulties, solving of educational problems (research, cognitive and communicative); control of the teacher, that becomes self-controlled, an assessment that gradually becomes self-assessment.

The activity component also implies "equal partnership of $\langle\ldots\rangle$ teacher and students in a joint, organized $<\ldots>$ teacher solution $\langle\ldots>$ by students learning tasks" [5, p. 87], reorientation from the philosophy of influence on the philosophy of interaction, cooperation, which means the pursuit of a common goal, an active, interested attitude towards joint activity. In this case, the information-controlling function of the teacher is steadily losing positions to the actual coordination function. L. Vygotskyi [14] emphasized that the teacher henceforth becomes only the organizer of the social educational environment, whose task is to regulate and control the interaction of each student with this environment [14, p. 192].

Independent activity is generally regarded as a multilateral and multifunctional activity. If there are many options regarding the definition of independent work, then in terms of its content by all researchers, it is uniquely interpreted as a purposeful, active, relatively free student activity.

The active definition of independent work is the one organized by the student by virtue of his internal cognitive motives, in the most convenient and rational, in his opinion, time that he controls himself by the results of indirect management of the latter by the teacher [15, p. 252].

The activity component should be implemented directly through the activities of future philologists in the foreign language to meet their educational needs in the light of future professional situations. It should be noted that the use of the interactive modern technologies (for example Moodle educational platform) contributes to the activity of independent educational and cognitive activity of the individual, provides a gradual and logical in mastering summary and abstract types of translations.

One of the characteristics of any activity is its motivation, because, as noted by $\mathrm{O}$. M. Leontiev, there is no activity without motive [5, p. 153].

Learning activities are motivated primarily by internal motives based on cognitive need, and external motives - prestige, self-affirmation, necessity, obligation [15, p. 84]. The success of independent work is determined by the dynamics of internal motives, the development of external social motives, and the convergence of external and internal motivation [15, p. 43].

T. I. Levchenko [6] believes that to ensure the effectiveness of learning it is necessary that the features of the construction and organization of the learning process correspond to the student's motivational sphere. 
Increasing the motivation of learning determines the intensity in the implementation of the selected action, the activity in achieving the result and purpose of the activity. With ascending motivation increases creative activity, intellectual capacity. Also changes to the better cognitive activity of the student. External influence on the learning subject can only be effective if the processes that take place inside (needs, interests, goals, intentions, individual style of activity, etc.) are taken into account. Determination by the stimulus of the sequence of educational actions, interaction of situational promptings and personal dispositions influence the motivation of learning. According to the theory of activity, motive is one of the determining components of activity.

It should be noted that the use of information and communication technologies contributes to the formation of motivation for independent learning of abstract and abstract types of translation, because the flexible and variational construction of the educational process allows the student to work remotely, at a convenient time for him and independently determine how much time he needs to work out materials convenient place, in terms of psychological comfort, that is, creates a mode of activity adequate to the motivational subtext of learning.

It is known that the formation of motivation is closely related to the activity itself and if the process of mastering the training material is successful, then it stimulates internal positive motivation, because there is a tendency to switch all motivational units to more successful activities [11, p. 75].

As students are characterized as a particular social category by professional orientation, professional motivation is important. In this regard, the first place is the correct choice of future profession and the adequacy and completeness of the student's ideas about the chosen profession, in particular knowledge of the requirements for it. The level of student's perceptions of the profession correlates with his or her attitude to learning: the more complete the idea of the profession, the more pronounced the positive attitude to learning [8, p. 9].

Acceptance of the profession gives rise to a desire to fulfill it. Students with high levels of social maturity have a pronounced professional self-determination, the main features of which is a meaningful and firm readiness for active independent activity in the chosen specialty, the desire to constantly improve it [9].

In this regard, the main factor that should be guided in the process of developing a method of self-translation by future philologists is their need for professional activity. And since activity always implies certain actions, so it is necessary, as noted by M.V. Grinova so that the learner should be aware of the purpose of their actions and "correlate them with the motives of the educational activity in which these actions are incorporated" [3, p. 31]. This is due, above all, to the specialist's awareness of the need to master these types of translation for future professional activity.

The principle of activity approach requires, first of all, understanding that learning is a joint activity of the teacher and the student, based on cooperation, where the end result is educational and cognitive activity, mental and practical operations and actions, conscious and purposeful regulation of the student's own teaching, formation of individual style of his educational and cognitive activity.

Therefore, the activity component should be implemented directly through the activities of future philologists in the French language to meet their educational needs in the light of future professional situations. It should be noted that the use of the electronic case promotes the activity of the individual educational and cognitive activity of the individual, provides a gradual and logical in mastering the written types of translation.

Therefore, the central categories of person-to-person activity approach in the context of independent work are secondary linguistic personality and independent, self-directed and productive activity of students, for the realization of which the main and effective means of learning scientists consider electronic means of education.

The analysis of scientific literature showed that for the organization of educational and cognitive activity of students, in particular independent extra-curricular work in a foreign language, scientists develop educational computer programs, to be precise, remote technologies, which allow to realize purposeful and methodically organized leadership of educational and cognitive activity of those who study and is based on the use of a wide range of traditional, informational and communicational technologies. For example, a learning organization based on the modern educational environment which is called Moodle that gives the opportunity to implement all the principles and factors of the person-to-person activity approach in the learning process of written translation.

Supporting the viewpoint of N.V. Mayer [7, p. 41], we believe that the combination of distance technologies (case technology and Internet technology) makes it possible to develop a computer-based learning tool - an electronic case - for independent translation by future translators. In the glossary of methodical terms, the case (from the English case - bag, briefcase) is considered as a set of educational materials on different media (printed, as well as audio, video, electronic), which are issued by students for independent work [1, p. 92]. Since a set of such materials in our case is placed on the Internet, it allows us to operate the concept of "electronic case".

Sharing the viewpoint of N. V. Mayer, we interpret the electronic case for training future translators of abstract and abstract types of translation as an electronic learning tool, which is available on the Internet and contains a set of teaching and methodical materials for students to develop translation skills, provides management of their independent learning and cognitive conditions using the means of self-control and indirect control by the teacher of the process and the result of mastering the relevant skills and abilities.

An electronic case based on the Moodle platform for translation as a learning tool, according to N.V. Mayer must perform the following functions: educational, controlling, motivating and informative, which act in organic unity [7]. To these functions we consider it necessary to add a communicative function, the realization of which is 
possible through the use of different types of activities of the electronic learning environment Moodle (Forum, Chat and others), on the basis of which this learning tool is developed. Let's take a closer look.

The educational function is the main one and involves the acquisition by future translators of educational material, necessary and sufficient for mastering the abstract and abstract types of translation and forming in them the relevant skills and abilities in independent extra-curricular work.

The control function is realized during the self-control by future translators of the process and the result of mastering the educational material, the formation of skills and abilities in written types of translation. It should be noted that due to self-control, there is self-reflection, self-analysis, which helps to increase the student's intrinsic motivation for self-learning.

The motivational function is ensured through the professional guidance of the electronic case study materials by modeling professional situations so that their work will be of interest to the students and meet their needs in future professional activity.

The informative function is realized by filling the electronic case with the necessary and sufficient background training materials so that working in extra-curricular conditions, the future translator does not waste time searching for the necessary educational information.

The communicative function is realized in the process of communicating the teacher with students and students with each other through the Internet tools provided in the Moodle learning environment (Forum, Chat and others).

In the course of independent mastery of the written translation the student works at an individual pace, according to his / her individual learning trajectory, the speed of performance of exercises and the strategy of mastering the educational material should be chosen by him / her, depending on his / her psychological characteristics, personal qualities and needs, regardless of other participants of the educational process makes the learning process personcentered. Freedom and flexibility are ensured in terms of duration and pace of exercise, choice of work mode, free time planning, which increases its motivation and promotes intensification of training. Positive intrinsic motivation is constantly increasing and maintained by encouraging students in the form of impartiality, positive teacher comments on their academic achievement. When developing an electronic case, students' age characteristics and their needs for future professional activity are taken into account. In addition, the use of electronic case contributes to the creation of a positive emotional background due to the confidentiality and objectivity of the evaluation of students' academic achievements [7].

In such circumstances, the student masters the educational material independently, at a distance, without direct intervention of the teacher in the process of his educational and cognitive activity, and also exercises self-control, which contributes to the formation of his reflexive skills.

Thus, we believe that the use of an electronic case has the following advantages when teaching translation and should provide:

- reducing the role of the subjective factor through objective control methods;

- possibility of systematic and prompt updating by the teacher of educational materials;

- intensification of the educational process;

- confidentiality;

- mobility and adaptability, which implies an appropriate level of preparation of the student for productive independent educational and cognitive activity [7];

- high level of interactivity;

- students' self-control over the process and the result of learning;

- content structuring (reference material (linguistic stylistic features of texts for translation and taking them into account when translating), transliteration rules with the ability to include links to other sources, grammatical reference, in particular, interphrase means typical for texts of a particular genre and their analogs in glossary of terms, subsystem of exercises for formation of skills and abilities (with an immediate response to the student's educational actions for the purpose of self-control); tasks for control of the teacher).

Therefore, students' independent work in the process of competence formation in translation should be based on the principles of personality-activity approach, since it is in the process of its implementation that the educational process becomes personality-oriented and provides maximum activity of all subjects of learning, which is actively reflected in motivation and effectiveness. learning process. Accordingly, the best way to implement a person-toperson approach is to consider information and communication learning tools, in particular the electronic case, which has several advantages in the process of teaching translation itself and performs important functions to ensure a quality educational process for the formation of the competence of future philologists in translation.

\section{References:}

1. Azimov, E. G. (2009). Novyj slovar'metodicheskih terminov i ponyatij (teoriia i praktika obucheniia yazykam) [A new dictionary of methodical terms and concepts (theory and practice of language teaching)]. Moscow : IKAR Publishing House [in Russian].

2. Galskova, N. D. (2000). Sovremennaya metodika obucheniya inostrannym yazykam [Modern methods of teaching foreign languages]. Moscow : ARKTI, 2000 [in Russian].

3. Grinova M. V. (2006). Samoregulyatsiia [Self-regulation]. Poltava : ASMI, 2006. [in Ukrainian].

4. Konysheva A. V. (2007). K voprosu ob osobennostyah upravlenii samostoyatelnoj rabotoj po inostrannomu yazyku studentov tehnicheskih specialnostei [To the question of peculiarities of managing self-study to teach foreign languages to students of 
technical specialities]. Vestnik Polockogo gosudarstvennogo universiteta. Seriya E. Pedagogicheskie nauki № 5 [in Russian].

5. Leontiev, A N. (1980). Izbrannye psihologicheskie proizvedeniya [Selected psychological works]. Moscow : Politizdat [in Russian].

6. Levchenko T. I. Rozvytok osobystisti v risnykh pedagogichnykh systemakh [Development of education and personality in different pedagogical systems ] / Monograph / T. I. Levchenko - 1st edition, - Vinnytsia: ed. Nova Knyha [in Ukrainian].

7. Maier, N. V. (2010). Metodyka samostijnoho ovolodinnia frankomovnym dilovym pysemnym spilkuvanniam majbutnimy dokumentoznavtsiamy $z$ vykorystanniam dystantsijnykh tekhnolohij [Methods of independent mastery of French-speaking business written communication by future document scientists using remote technologies]. Thesis cand. ped. of sciences.: spec. 13.00.02 "Theory and Methods of Learning" [in Ukrainian].

8. Modern student in the context of personality-activity approach: according to the results of scientific-pedagogical researches: Collective monograph / O. B. Bigich, M. S. Voloshyna, M. S. Glazunov et al. Kyiv : Publishing center of KNLU, 2014 [in Ukrainian].

9. Pestalozzi, I. G. (1981). Izbrannye pedagogicheskie sochineniia [Selected pedagogical works]. In 2 volumes. - Vol.1. - Publisher "Pedagogika" [in Russian].

10. Petrovska, Yu. V. (2005). Problemi avtonomnogo navchannya inozemnoyi movi u vishih tehnichnih navchalnih zakladah [Problems of autonomous learning of foreign language at haigher technical educational establishments]. Mizhnarodnij forum. Movna osvita: shlyah do yevrointegraciyi [in Ukrainian].

11. Polat, E. S. (1998). Distantsionnoe obuchenie: Uchebnoe posobie dlia vuzov [Distance Learning: Textbook for Universities] / Evgenia Semenovna Polat. Moscow : Vlados [in Russian].

12. Richards, Kyiv, Roe, P. (2004). Distance Education: New Perspectives. Macmillan Publishers Ltd [in English].

13. Shchukin, A. N. (2007) Lingvodidakticheskij enciklopedicheskii slovar: bolee 2000 slov [Linguodidactic dictionary: more than 2000 words]. Moscow : Astrel: AST: Hranitel [in Russian].

14. Vygotskii, L. S. (1982). Sobranie sochinenii: Problemy obshej psihologii. [Collected edition: problems of general pedagogics]. Moscow : Pedagogika [in Russian].

15. Zimniaia, I. A. (2000). Pedagogicheskaia psihologiia. Uchebnik dlia vuzov [Pedagogical psycology. Text book for higher educational establishments]. Moscow : Izdatelskaya korporaciia «Logos» [in Russian].

Ігнатенко В. Д., Пилипей Ю. А. Особистісно-діяльнісний підхід до самостійного оволодіння письмовим перекладом

Стаття присвячена проблемі самостійного оволодіння письмовим перекладом майбутніми філологами у контексті особистісно-діяльнісного підходу до навчання. У статті окреслено поняття і місце самостійної роботи студентів у сучасному освітньому прочесі. Увага фокусується на особистісно-діяльнісному підході як ефективному засобу реалізації сучасних освітніх иілей, який максимально задовольняє навчально-пізнавальні потреби сучасних студентів. Також аналізується поняття особистісно-діяльнісного підходу в історичному контексті. Особистісно-діяльнісний підхід розглядається у двох аспектах, а саме особистісному і діяльнісному, які взаємопов'язані та поділяються лише умовно. Особистісний компонент направлений на формування вторинної мовної особистості, що є актуальним для майбутніх філологів, і передбачає розвиток особистості в иілому. Діяльнісний компонент базується на засадах суб 'єкт-суб'єктних відносин між студентами та викладачем, на рівно партнерському співробітництві, щчо передбачає інтенсивну навчально-пізнавальну діяльність студентів, зокрема учіння, тобто студент засвоює науку та культуру, будучи активним учасником освітнього процесу, а не спостерігачем/слухачем. Це забезпечує позитивний інтелектуально-емоиійний контекст навчальної діяльності, можливість кожного виявити власну активність, креативність та самостійність. Таким чином, иентральними категоріями особистісно-діяльнісного підходу в контексті самостійної роботи є вторинна мовна особистість та самостійна та продуктивна діяльність студентів, для реалізаиії якої основними та ефективними засобами навчання науковці вважають електронні засоби навчання, а саме дистанційні технології, які дозволяють реалізувати цілеспрямоване та методично організоване керівництво навчальною та пізнавальною діяльністю тих, хто навчається, і базуються на використанні широкого спектру традиційних, інформаційних та комунікаційних технологій.

Ключові слова: особистісно-діяльнісний підхід, перекладаџька компетентність, іноземна мова. 